A. Viknianska1, orcid.org/0000-0001-7595-2856, D. Kharynovych-Yavorska ${ }^{2}$, orcid.org/0000-0002-8988-5313, M. Sahaidak ${ }^{3}$, orcid.org/0000-0001-6526-1170, A. Zhavoronok ${ }^{1}$, orcid.org/0000-0001-9274-8240, V. Filippov ${ }^{4}$, orcid.org/0000-0003-4429-7582
1 - Yuriy Fedkovych Chernivtsi National University, Chernivtsi, Ukraine

2 - Kyiv Cooperative Institute of Business and Law, Kyiv, Ukraine

3 - Kyiv National Economic University named after V. Hetman, Kyiv, Ukraine, e-mail: sahaidak@kneu.edu.ua

4 - Educational and Research Institute of Business, Economics and Information Technology, Odesa National Polytechnic University, Odesa, Ukraine

\title{
METHODOLOGICAL APPROACH TO ECONOMIC ANALYSIS AND CONTROL OF ENTERPRISES UNDER CONDITIONS OF ECONOMIC SYSTEMS TRANSFORMATION
}

Purpose. To substantiate the methodological approach to the development of research components of the integrated system of complex economic analysis and internal control of the enterprise.

Methodology. The main methods of this research are statistical methods, the latter being used for processing of statistic data; methods of formalization and mathematical simulation used for development of conceptual analysis base to control the enterprise's activity.

Findings. A complex model of diagnostics of enterprises' activity in a competitive environment is proposed, which is based on the methodology of complex economic analysis with the use of financial and non-financial indicators. To assess the competitive advantages of the enterprise, we offer an algorithm to calculate an integrated indicator of the level of its competitiveness using a balanced scoring system.

Originality. In the course of research, the scientific and methodological approach to a complex evaluation of influence of a research component on development of competitive strategy of the enterprise was developed. Unlike the existing ones, this approach involves:

- development of an integrated system of complex economic analysis and internal control over business processes of enterprises with the use of modern information technologies, which allows assessing their competitiveness, forming a development strategy;

- methodical procedures of internal control of the enterprise with the use of financial and operational budgets and management reports based on a balanced scoring system, using CVP-analysis, which allows forming flexible budgets.

Practical value. The results of the study can be used by practitioners, scientists, government officials to monitor the development of the corporate architecture, to study enterprise development processes.

Keywords: competitive environment, complex economic analysis, internal control, balanced scoring system

Introduction. The definitive feature of the current stage of development of the world leading countries is a high degree of dynamism and variability, which is based on rapid scientific and technological progress and prompt implementation of innovations in the production process. Expansion of the principles of complex economic analysis and internal control is steadily becoming a global trend, which involves the activation of intellectual resources, innovation, scientific and technological development, the practice of implementation of modern information and communication technologies in the activities of economic entities.

The importance of solving such problems as search for efficient ways of resource conservation, increase in profits and cost-effectiveness in lieu of risk mitigation, creates the necessity to improve organization and methods of complex economic analysis and control, which will help to reach sufficient level of competitiveness of an enterprise.

Literature review. The methodological basis of the study on enterprises which are functioning under the influence of the economic system's transformation is disclosed in the publications by Antoniuk, et al. [1], Grigoraş-Ichim, et al. [2], Shkarlet, et al. [3], Dubyna, et al. [4]. Descriptions and features of complex economic analysis and internal control are specified in the papers by Socoliuc, et al. [5], Bieliaieva [6], Bilan, et al. [7], Mykhailenko [8], Tamulevičiené [9].

Nowadays researchers study various aspects of comprehensive assessment of enterprise activity. Sahaidak, et al. [10]

(C) Viknianska A., Kharynovych-Yavorska D., Sahaidak M., Zhavoronok A., Filippov V., 2021 studies the comprehensive assessment of influence of the innovative development asymmetry on functioning of the enterprise. Grigashkina, et al. [11] studies the comprehensive assessment of Stabilization Factor for enterprises during the Crisis Period. Zavalko, et al. [12] have researched methods to diagnose the probability of financial crisis at the enterprise.

Zybareva, et al. [13], Ivashchenko, et al. [14], Shkarlet, et al. [15] considered the peculiarities of strategic management of the enterprise's activities to maintain an effective functioning in the competitive environment.

Unsolved aspects of the problem. The scientific achievements of these scientists are undoubtedly important for shaping the theoretical foundations of the complex economic analysis and internal control. However, the issues of comprehensive study on factors and identification of patterns of development of strategic financial plan based on enterprise value indices in the context of steady growth development remain open. The methodological toolkit of assessing components of the balanced scoring system based on KPI (Key Performance Indicators), as well as the analytical characterization of the influence of the researched component on the dynamics of the business strategy of an enterprise (growth, stabilization, restructuring, acquisition) needs improvement.

The purpose of the article is to substantiate the methodological approach of development of research components of an integrated system of complex economic analysis and internal control of business activities of enterprise that allows evaluating competitiveness of an enterprise and forming development strategies, necessary for gaining a competitive edge. 
Methods. In the course of research, a set of general scientific and special methods of cognition were used: logical generalization - for structural components of complex economic analysis and internal control; quantitative and qualitative comparisons - for the study on the mutual influence of science (research activity) and complex economic analysis and control; taxonomic and index analysis - to build an integral indicator of the impact of the research component on the information economy development; graphic visualization - for visual display of information; scientific abstraction and systematization - to substantiate suggestions to improve approaches of estimated turnover expenses and solvency management using CVP-analysis model.

Results. Complex economic analysis and internal control. Based on research $[5,9]$ it has been concluded, that a unified approach to organization of analysis and control, which would objectively reflect the demands of all interested parties, does not exist. That is why we propose a sequence of analytical and managerial measures to create competitive advantages, based on complex economic analysis and control, aimed to effectively manage enterprise business activities. This sequence has three main stages (Fig. 1).

It also allows management to set goals that an enterprise must achieve by means of efficient management. Examples of such goals include EBIT, EBITDA indices, or business value, indicated by EVA economic added value.

According to the concept of value-based management, in order to maintain a company, it is necessary that the owner's profit should be at least on par with the opportunity cost of capital that the owner has invested in the company, that is, equal to the return on alternative investments with similar risk. To maintain a fixed (stable) value, it is necessary that the owner's return on each completed project should be not lower than the alternative cost of capital invested by the owner in the project. A positive range between project profitability and opportunity cost of capital signals an increase in value and forms the basis of the structure of the Economic Value Added indicator $(E V A)$. The higher the profitability (return) of a project is, the more cost-effective the project is based on this criterion. EVA is calculated using the following formula when evaluating the performance of a business organization

$$
E V A=\left(R O E-r_{e}\right) \times E,
$$

where $R O E$ is return on equity, $\% ; r_{e}$ is opportunity cost of equity, \%; $E$ is equity, monetary unit; $E V A$ is economic value added, monetary unit.

To identify the increase in value for the owner from the investment [21]

$$
E V A_{i}=\left(R O E_{i}-r_{e i}\right) \times E_{i},
$$

where $R O E_{i}$ is return on equity of the project, $\% ; r_{e i}$ is opportunity cost of equity, \%; $E_{i}$ is equity used to finance the project, monetary unit; $E V A_{i}$ is Economic added value of the project, monetary unit.

Accounting for $(1,2)$ allows us to determine the analytical model that will be used to measure the economic profit of an enterprise that can be considered as an internal source of investment. Measuring economic profit using the Economic Value Added (EVA) model allows you to calculate the fundamental (market) value of an enterprise. The fundamental value of an enterprise reveals its dual nature: on the one hand, as a subject of economic relations, whose main function is the development, production and sale of economic goods (that is, as a source of self-increase in capital, value creation), on the other hand - as an investment item of goods (an object of investment interests of owners and other participants in market processes).

Implementation of fundamental cost analysis of the performance of an enterprise allows one to determine the following sequence and directions of such assessment: analysis of the dynamics and structure of the fundamental value of the enterprise; analysis of the dynamics and structure of the book value of net assets of the enterprise; analysis of the spread of capital return (Spreadcap), spread of profitability of sales of products (Spreadsale) and factors of their formation.

A cost-based approach to assessing the performance of an enterprise involves not only ensuring the formation of added value on the invested capital, but also its growth. One of the methods of cost growth estimation is to calculate the Sustainable Growth Index $(S G I)$

$$
S G I=g_{s} \frac{l}{k} \sum_{i=1}^{k} \max \left[0 ;\left(R O C E_{i}-W A C C_{i}\right)\right],
$$

where $g_{s}$ is the average sales growth rate; $l$ is the number of years during which the capital return spread is a positive value; $k$ is the number of years of observations; $R O C E_{i}$ is return on invested capital in the $i$ year; $W A C C_{i}$ is weighted average capital expenditures in the $i$ year.

So, to assess the performance of an enterprise, based on the logic of a multi-factor interpretation of the EVA model, it is proposed to take the value of the Economic Value Added of the enterprise, the factor interpretation of which is presented on the basis of formulas

$$
\begin{gathered}
E V A=\text { Cap } \times \text { Spred }_{\text {cap }} ; \\
E V A=\text { Cap } \times \text { Product }_{\text {ass }} \times \text { Spred }_{\text {sale }} ; \\
\text { EVA }=\text { Sale } \times \text { Spred }_{\text {sale } .} .
\end{gathered}
$$

If the EVA indicator is $\geq 0$, it means that the return on assets compensates for financial risks, and the functioning capital ensures the formation of added value. This analytical premise is the basis to identify a high level of performance of the enterprise. If $E V A \leq 0$, the situation can be as follows:

- the enterprise is profitable (Net Income, $N I>0$ ), but the level of return on assets is insufficient to cover the cost of capital. Profitability of activities is evidence to ensure operational and strategic efficiency of activities and a strong argument to recognize the level of performance as normal;

- the enterprise is unprofitable $(N I<0)$, which requires additional financial calculations to determine the level of performance of the enterprise, which is advisable to carry out in such projections: the ability to meet the requirements of financial stakeholders; sufficient funds to finance current and investment activities; the level of financial independence from external investors and creditors.

In the projection of the ability to meet the requirements of financial stakeholders (liquidity), it is advisable to use the traditional system of liquidity indicators (absolute, intermediate and current liquidity coefficients), as well as to include the following indicators:

- coefficient of the growth rate ratio of the of current assets to the growth rate of the enterprise's debt;

- ratio of accounts payable and receivables.

However, achievement of such goals is impossible without utilization of financial and non-financial indices, often called the key performance indicators.

According to this approach, there is an opportunity to assess and analyze an enterprise's market position, social efficiency of enterprise activity and to determine its business value, taking into account the probability of financial impendences, risk and inflation processes. Organizational stage combines the following phases.

Phase I - in the event of creation of enterprise, a general strategy of business development and long-term outlook of an enterprise is created. The structure of financial resources (outlook of assets structure change, priorities of investment and funds attraction) is based on this strategy. In the event of a functioning enterprise, the management has to establish goals of its activities.

Phase II provides for creation of a unified database that will accumulate accounting information: financial, managerial and statistical. In such a manner the system will allow obtaining information needed to solve the task of strategic manage- 
ment, based on integration of accounting and analytical processes, since financial accounting only provides an aggregated presentation of state of affairs of an enterprise, and is largely intended for use of external shareholders. Managerial ac- counting is oriented on the management decision-making, based on information that is confidential.

Phase III (main stage) includes study on results of enterprise business activities in competitive environment, which

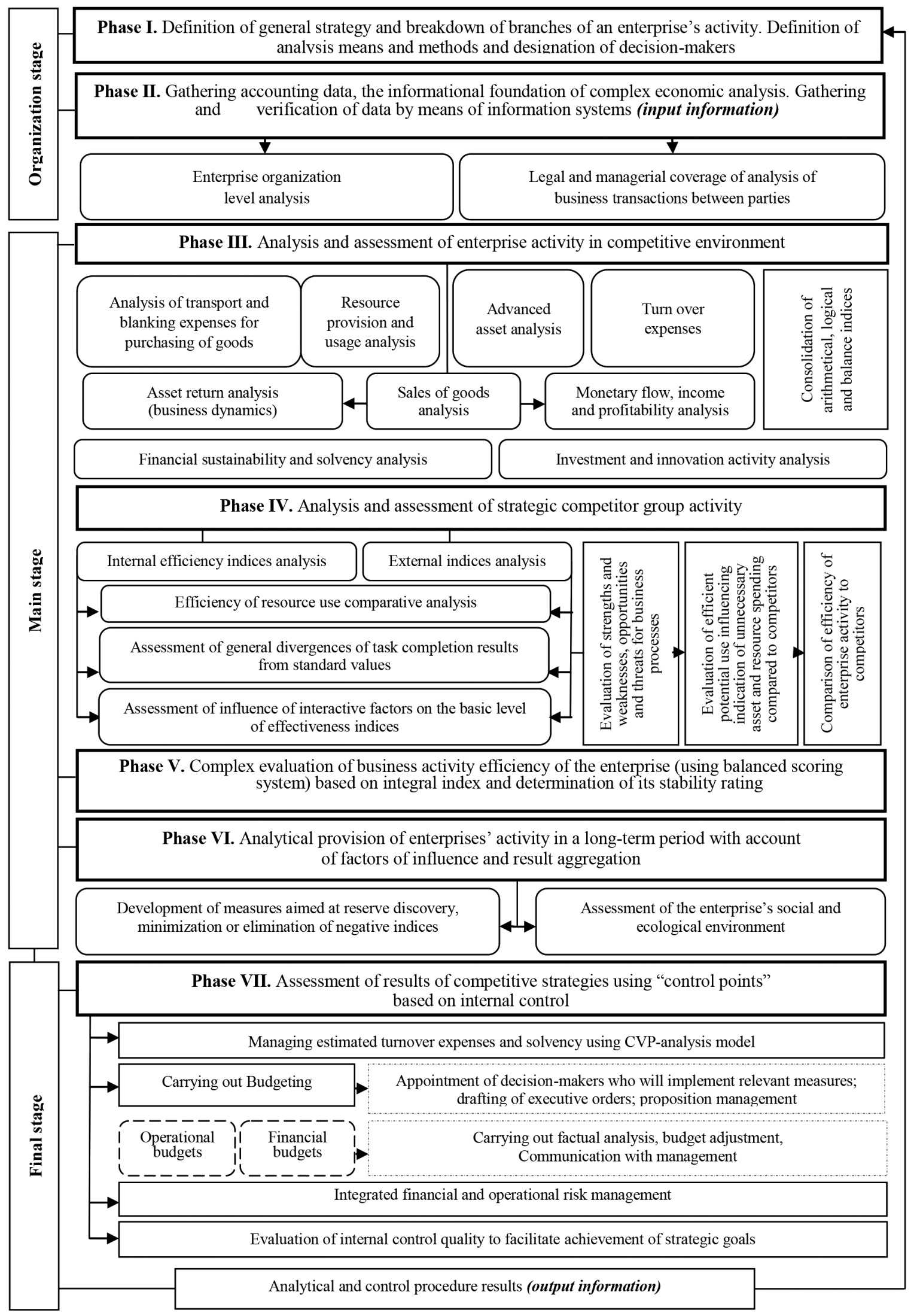

Fig. 1. Phases of complex economic analysis and internal control of enterprise activity 
requires analysis of the enterprise presence on the external market and evaluation of possible lost advantages of its functioning and financial assessment. Any analytical process has to be carried out utilizing single adopted framework that will provide the conclusion about the state of affairs of an enterprise in question.

Based on the research on scientific viewpoints concerning the sequence of financial state analysis, we may agree with the findings of 2018 [12] that the main components of such sequence are analysis of structure and dynamics of assets and liabilities (16.6\%), liquidity and credit worthiness $(14.3 \%)$, monetary flow (16.6\%), financial sustainability (14.3\%), economic activity (14.3\%), probability of bankruptcy (14.3\%). The author [2] puts that, "the study on methods of financial state analysis by various authors proves not only the absence of a unified system of estimated figures aimed at defining the level of an enterprise financial sustainability, as well as liquidity and credit worthiness, but also existence of different terms for indices, calculated using the same algorithm, and same terms for indices, calculated by different means". This view is endorsed by [16] who points out the absence of unified scientifically based statutory terms for values of financial state indices even from a perspective of branches of business activities.

That is why the foregoing developments do not meet the criteria required for complex and complete analysis.

Methodological recommendations issued by various ministries and agencies are in most cases used during analysis of financial state in the event of financial audits, privatization, bankruptcy, financial rehabilitation and do not provide complex economic analysis.

However, it would be more rational to carry out organizational procedures in economic analysis of enterprise business activities under the conditions of economy transformation, including optimization of analytical information relevance. A number of scientists point out this problem [17, 18].

Phase IV - conduction of the analysis of strategic competitors' groups' functioning efficiency.

Phase $V$ - includes evaluation of competitive advantages of enterprises in question, based on integral index of balanced scoring system and formation of the rating of stability of such indices.

We agree with the viewpoint of the author [18, 19] who states that restricting economic analysis to "divergences analysis", as it is interpreted by some foreign economists, is faulty, as such analysis is only a single specific element in the management system.

Orientation on market value changes the vector of enterprise value management during all stages of strategy development. As such, it is necessary to utilize interconnected series of financial and non-financial indices, namely the balanced scoring system based on KPI (Key Performance Indicator), displayed as "strategic map". This allows reflecting the business strategy of an enterprise (growth, stabilization, restructuring, acquisition) in complex series of indices necessary for strategic planning and evaluation of achieved results in financial reference period which will facilitate competitiveness and potential. These indices must include all aspects of enterprise activity, and their fulfillment is the task not only for financial service specialists, but also for another employees.

Taking into account that the system allows structuring of data flows that improve the quality of management staff communication and efficiency of carrying out its duties, as well as the efficiency of enterprise activity as a whole, the aforementioned system should be construed as basis in formation of the controlling an analytical system of an enterprise, it should be mentioned that the main strategic financial index of enterprise activity has to be developed. In our opinion, the main goal of the enterprise is its value increase as the main strategic financial index, which allows evaluating and analyzing business success and management efficiency over time. Therefore, we propose to establish the following index - enterprise market value adjusted for net income and assets value that can be used to determine the rating of an enterprise in competitive environment.

The last phase in main stage is Phase VI, which allows forming predictable competition strategies and selection of optimal strategy by the enterprise management using key parameters (net income, gross income, sum of reserves and value of floating assets). Therefore, study on theoretical basis of complex economic analysis and internal control of enterprises activity in competitive environment has given an opportunity to define the means of its improvement.

Complex model. The task is to identify problems in a complex manner, as well as to identify and develop specific means aimed at mitigation of negative impact and normalization of financial state combined with decrease in duration of periods between routine index measurements, which constitute the base of continuous scanning.

It is possible only when managerial decisions are made with accounting of evaluation of future ability of the enterprise to generate monetary flow, accumulate income and create additional value, as well as opportunities for efficient use of their own and loaned currency.

The results of these operations will be the ability to mobilize financial resources into most profitable branches of activity and creation of efficient means to counter risks and early indications of stagnation that occur in business activities with evaluation of bankruptcy probability.

This approach requires balanced forms of process assessment, technology of development and making of managerial decisions which are based on system analysis methodology with the following characteristics: aimed at operations and functioning; perspective nature of analysis; evaluation of business elements and business processes efficiency in the structure of an enterprise.

Taking the above into account we propose a complex model of an enterprise activity assessment, which is an integrated communication system aimed at achieving profitability in short-term perspective with further evaluation of net monetary flow (Fig. 2).

Assessment technology is comprised of seven modules. The first module is "Preparatory procedures" - assembly of team of experts, that require selection of specialists from the enterprise staff, as well as outsourcing of analyst personnel, that has sufficient training and skills to carry out the assessment; articulation of aim of assessment that defines its essence and methods; specification of tasks of analysis that clarify and elaborate the goal of assessment; drafting the plan of assessment that includes description of sequence of actions taken to evaluate the financial state based on specific parameters.

The first module is aimed to solve the organizational tasks of assessment. The second module is provision of prompt communication during the process of assessment. Within its limits data search and gathering is conducted, as well as selection of relevant data and processing of it into a human-friendly form.

Within the limits of the third module the internal control service selects the analytical instruments of the assessment. Certain tasks are being specified, since earlier modules may have uncovered facts that need additional elaboration.

Within the third module, the internal control service selects analytical diagnostic tools. Tasks are being clarified, because during the implementation of previous modules, facts that provide for such actions may have been revealed.

Analysts determine the parameters and evaluation indicators that most accurately and objectively characterize the level of efficiency of the enterprise's functioning in the market as a whole or in its individual segments and allow us to track their change in dynamics.

The fourth module provides identification for the most influential factors of surrounding environment and evaluation of their impact capability.

The fifth module is an assessment of internal environment factors. This assessment defines parameters of quality of orga- 
nizational structure and selection of indices of enterprise activities success.

Summary of assessment results is conducted within the limits of the sixth module. Then the analysis of obtained results is carried out - identification of divergences from desired indices, reasons for these deviations and identification of directions of reserve growth.

The result of introduction of this model is an opportunity to balance asset and monetary flow, reduce informational risks, creation of efficient means to counter risks and

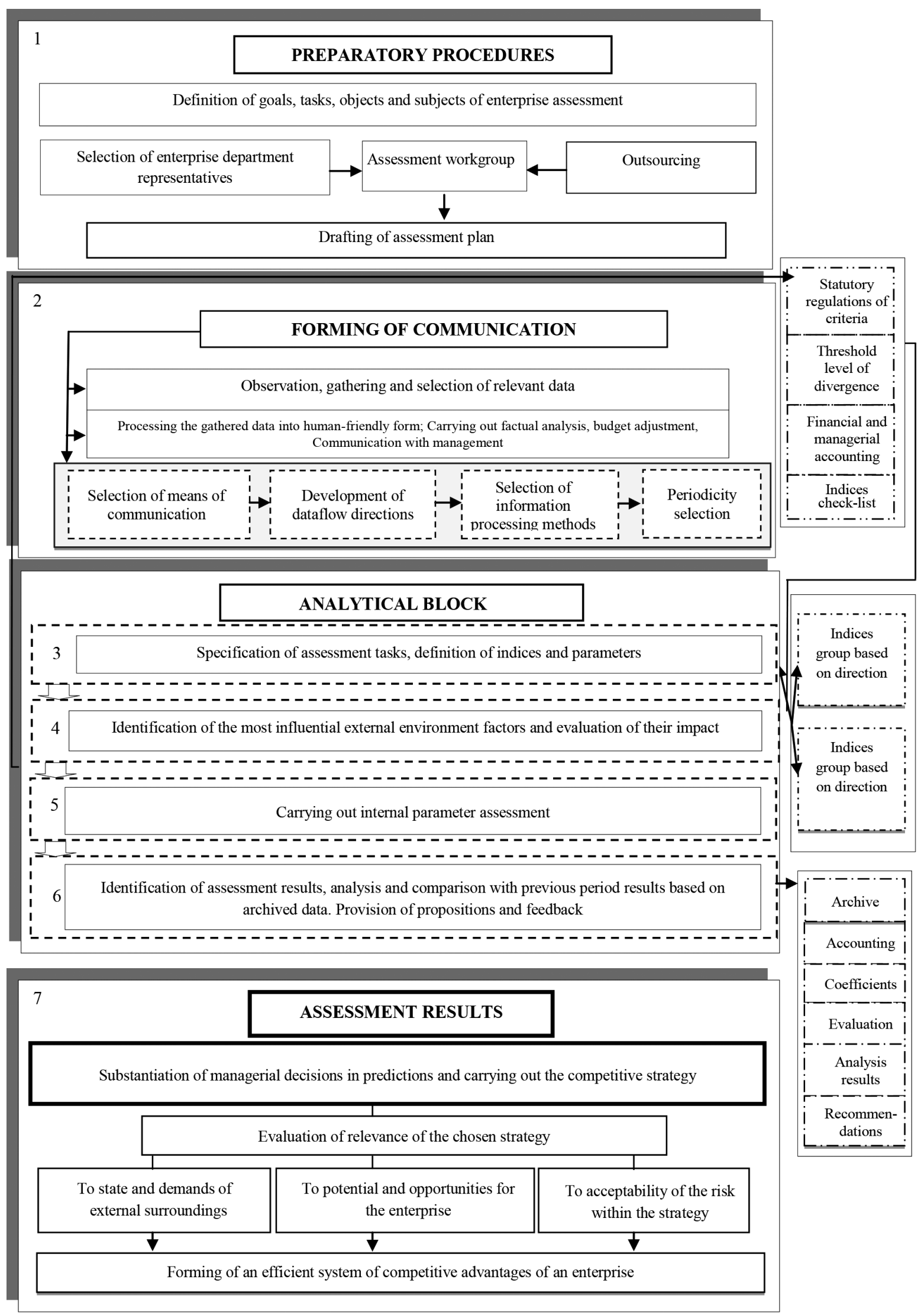

Fig. 2. Complex model of enterprise activity assessment 
early signs of stagnation that occur in enterprise business activities.

Algorithm of evaluation of competitive advantages. By virtue of critical analysis of existing methodological approaches to evaluate competitiveness based on evaluation of competitive advantages, taking the necessity of accuracy and relevance of calculations into account, we propose an algorithm of competitive advantage evaluation, utilizing complex (integral) index of competitiveness level based on balanced scoring system (Fig. 3).

Reproduction of financial resources based on the process approach is seen as continuous accumulation of working capital, much of the value of which is means to form inventory at commercial enterprises.

A reproduction of financial resources appears as efficiency of inventory and determines their optimal level as competitive advantage while acting as uniformity of flow of goods to the enterprise, the average duration of one turnover, the level of inventory per unit of turnover, minimization of costs, optimi- zation of the volume and timing of orders, balance indicators formation plan and plan of inventory turnover.

Competitive advantages that provide social efficiency of activities are improvement of working conditions, matching of the amount and structure of inventories to consumer demand, the quality of services that are prerequisite for competitiveness.

Assessment projection of our proposed development and improvement should be seen in the system of enterprise competitiveness as one that integrates other subsystems and determines the effectiveness of their formation and use. So, in this projection we allocated productivity, staff turnover, profitability of personnel costs, advance turnover ratio over the cost of a unit of work, cost per unit of work, the level of employee satisfaction with working conditions, increase in average wages.

This methodic approach has several advantages: it is logical and therefore is an accessible analysis instrument; it accounts for industry-wise specifics of enterprise functioning with the help of selected financial and non-financial indices that increase its accuracy.

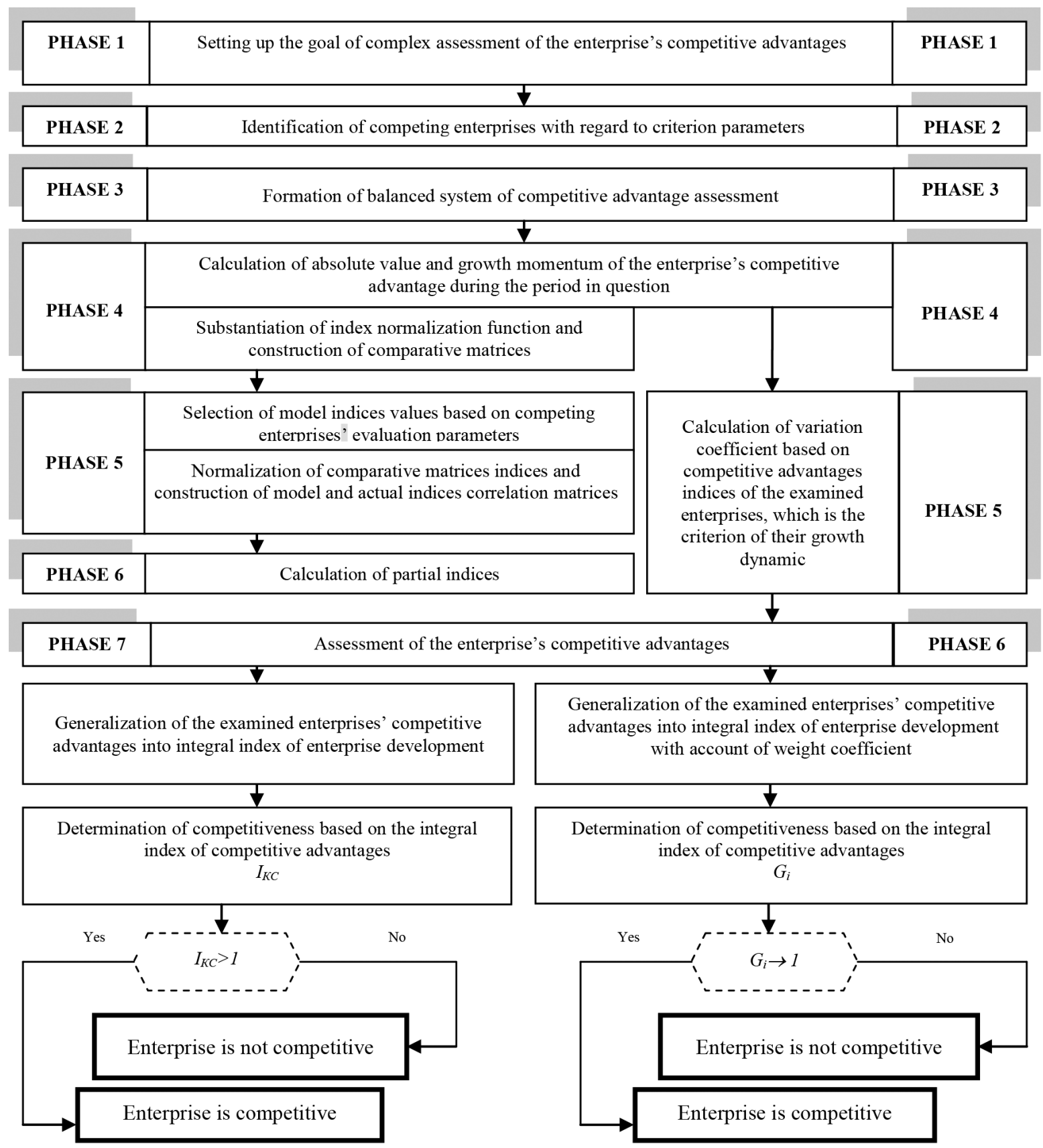

Fig. 3. Algorithm of evaluating the enterprise's competitive advantages 
Testing of this technique in managerial accounting during 2013-2019 period at several enterprises proves its relevance, while regular monitoring of these enterprises' activities provides an opportunity to study the main tendencies of enterprise growth and react to any negative symptoms in advance.

Conclusions. Changes in the competitive environment and the need for commercial enterprises to improve the quality of management require obtaining and evaluating information to identify and overcome operational and financial risks in a timely manner, improve business processes and make management decisions to enhance their competitiveness. This is possible through the improvement of comprehensive economic analysis and reform of controls in accordance with international standards of quality control, audit, review, other assurance and related services. Therefore, in the practice of economic relations, management entities formulate requests for control and analytical support in order to increase competitiveness.

The complex economic analysis and internal control of the enterprise activity is proposed to be carried out in the following sequence: definition of the general strategy and goals of the enterprise activity; obtaining accounting data for complex economic analysis; analysis of the condition and diagnostics of the activity of the basic enterprise; analysis and diagnostics of performance of competitors; comprehensive evaluation of the performance of companies using a balanced scoring system and based on an integrated competitiveness indicator and rating based on their sustainability; formation of competitive strategies of enterprise activity for short and long term taking into account factors of influence of competitive environment; evaluating the achievement of a competitive strategy through internal control. This will improve the management system of the enterprise and reduce the risk of loss of competitive advantage.

A complex model of diagnostics of enterprises' activity in a competitive environment is proposed, which is based on the methodology of complex economic analysis using both financial and non-financial indicators, whose main task is to identify problems of enterprises, identify and develop measures aimed at eliminating the negative impact of environmental factors and normalization of their financial condition. As a result, management will identify additional opportunities for efficient use of its own and borrowed funds, mobilize financial resources in the most profitable areas of activity and apply effective mechanisms for counteracting risks, early signs of crisis and the likelihood of bankruptcy.

To evaluate the competitive advantages of an enterprise, an algorithm for calculating a complex (integral) indicator of its competitiveness level for the relevant period was developed, using a balanced system of indicators, which allows evaluating comprehensively the level of development of an enterprise and the level of its advantages over direct and potential competitors in individual segments market or in general. The proposed methodological approach allows distinguishing dynamically developing companies with high level of reliability and financial sustainability and maintaining a consistently high level of competitive advantages over competitors in the short and long term.

Having studied the practice of enterprises' activity and their corporate architecture, we propose the following: expansion of informational opportunities for business planning with developed budget model based on introduction of corporate software products for large businesses and mixed budgeting system in MS Excel environment with the use of interconnected tables, charts and diagram for medium businesses; execution of internal control tasks that depend on an enterprise's strategic goals and processing of analytic inquiries in real time, as well as based on hybrid (mixed) cloud technologies.

We propose a generalized chart of informational technologies detailing complex economic analysis subsystems and internal control of an enterprise's main activity for the use of continued control of enterprise business processes by management staff.

\section{References.}

1. Antoniuk, L., Gernego, I., Dyba, V., Polishchuk, Ye., \& Sybirianska, Yu. (2017). Barriers and opportunities for hi-tech innovative small and medium enterprises development in the $4^{\text {th }}$ industrial revolution era. Problems and Perspectives in Management, 15(4), 100-113. https:// doi.org/10.21511/ppm.15(4).2017.09.

2. Grigoraș-Ichim, C. E., Cosmulese, C. G., Savchuk, D., \& Zhavoronok, A. (2018). Shaping the perception and vision of economic operators from the Romania - Ukraine - Moldova border area on interim financial reporting. Economic Annals-XXI, 173(9-10), 60-67. https://doi.org/10.21003/ea.V173-10.

3. Shkarlet, S., Dubyna, M., Shtyrkhun, K., \& Verbivska, L. (2020). Transformation of the Paradigm of the Economic Entities Development in Digital Economy. WSEAS Transactions on Environment and Development, (16), 413-422. https://doi.org/10.37394/232015.2020.16.41.

4. Dubyna, M., Zhavoronok, A., Kudlaieva, N., \& Lopashchuk, I. (2021). Transformation of Household Credit Behavior in the Conditions of Digitalization of the Financial Services Market. Journal of Optimization in Industrial Engineering, 14(1), 97-102. Retrieved from http:// www.qjie.ir/article 677835 24626a93c37b1800694e93681e8f6a79.pdf. 5. Socoliuc, M., Cosmulese, C.-G., Ciubotariu, M.-S., Mihaila, S., Arion, I.-D., \& Grosu, V. (2020). Sustainability Reporting as a Mixture of CSR and Sustainable Development. A Model for Micro-Enterprises within the Romanian Forestry Sector. Sustainability, 12, 603. https://doi.org/10.3390/su12020603.

6. Bieliaieva, N.A. (2017). Financial and economic activities effectiveness evaluation as a condition of corporate management decisions making. Baltic Journal of Economic Studies, 3(4), 12-17. https://doi. org/10.30525/2256-0742/2017-3-4-12-17.

7. Bilan, Y., Nitsenko, V., Ushkarenko, I., Chmut, A., \& Sharapa, O. (2017). Outsourcing in international economic relations. Montenegrin Journal of Economics, 13(3), 175-185. https://doi.org/10.14254/18005845/2017.13-3.14

8. Mykhailenko, D. H. (2018). Economic efficiency: definition, analysis of concepts. Problems of the economy, 2(36). Retrieved from http:// oaji.net/articles/2017/728-1536643428.pdf.

9. Tamulevičiené, D. (2016). Methodology of complex analysis of companies' profitability. Entrepreneurship and sustainability issues, 4(1), 53-63. https://doi.org/10.9770/jesi.2016.4.1(5).

10. Sahaidak, M., Tepliuk, M., Zhurylo, V., Rudenko, N., \& Samko, O. (2021). Integrative Viewpoint for Implementing Sustainable Management Agricultural Business Excellence. TEM Journal, 10(1), 303-309.

11. Grigashkina, S., Garafonova, O., \& Marhasova, V. (2018). Stabilization Factor for Enterprises during the Crisis Period. E3S Web of Conferences, 41, 04006. https://doi.org/10.1051/e3sconf/20184104006.

12. Zavalko, N.A., Kozhina, V. O., Kovaleva, O. P., Kolupaev, R. V., \& Lebedeva, O. Ye. (2018). System Approach to Diagnostics and Early Prevention of a Financial Crisis at an Enterprise. Journal of Applied Economic Sciences, 13(1), 84-88.

13. Zybareva, O., Verbivska, L., Lopashchuk, I., Kalaman, O., Derkach, T., \& Smentyna, T. (2019). Strategically-Oriented Enterprise Management through Information Systems. International Journal of Recent Technology and Engineering (IJRTE), 8(2), 3014-3017.

14. Ivashchenko, A., \& Polishchuk, Y. (2018). Machine learning in estimating of SMEs investment potential in Ukraine. CEUR Workshop Proceedings, 2105, 77-93.

15. Shkarlet, S., Kholiavko, N., \& Dubyna, M. (2015). Territorial reform in the system of strategic management of energy-economic and information spheres of the state. Economic Annals-XXI, (5-6), 103107. Retrieved from http://soskin.info/userfiles/file/2015/5-6\%20 2015/Shkarlet_Kholiavko Dubyna.pdf.

16. Urkayev, M.H., Karimov, F.J., Gurbanova, Kh.V., Karimova, M. N., \& Karimova, I.J. (2019). Methods of management accounting and economic analysis. European journal of economics and management sciences, (2), 13-24.

17. Gritsenko, O. I. (2015). Economic cost analysis of service quality as a factor of sustainable development of enterprises. Economic Processes Management: International Scientific E-Journal, 1. Retrieved from http://oaji.net/articles/2015/935-1426154726.pdf

18. Korepanov, G., Yatskevych, I., Popova, O., Shevtsiv, L., Marych, M., \& Purtskhvanidze, O. (2020). Managing the financial stability potential of crisis enterprises. International Journal of $A d-$ vanced Research in Engineering and Technology, 11(4), 359-371. 19. Latysheva, O., Rovenska, V., Smyrnova, I., Nitsenko, V., Balezentis, T., \& Streimikiene, D. (2020). Management of the sustainable development of machine-building enterprises: a sustainable development space approach. Journal of Enterprise Information Management, 34(1), 328-342. https://doi.org/10.1108/JEIM-12-2019-0419. 


\section{Методологічній підхід до проведення економічного аналізу й контролю підприємств в умовах трансформації економічних систем}

А. В. Вікнянська ${ }^{1}$, Д. О. Харинович-Яворська ${ }^{2}$ М. П. Сагайдак ${ }^{3}$, А. В. Жаворонок ${ }^{1}$, В. Ю. Філіппов ${ }^{4}$

1 - Чернівецький національний університет імені Юрія Федьковича, м. Чернівці, Україна

2 - Київський кооперативний інститут бізнесу та права, м. Київ, Україна

3 - Київський національний економічний університет імені Вадима Гетьмана, м. Київ, Україна, е-mail: sahaidak@kneu.edu.ua

4 - Інститут бізнесу, економіки та інформаційних технологій Одеського національного політехнічного університету, м. Одеса, Україна

Мета. Обгрунтувати методологічний підхід до розробки складових дослідження інтегрованої системи комплексного економічного аналізу та внутрішнього контролю діяльності підприємства.

Методика. До основних методів дослідження можна віднести: статистичні методи - для опрацювання масивів статистичної інформації; методи формалізації й математичного моделювання - для розробки концептуальних снов аналізу діяльності підприємств.

Результати. Запропонована комплексна модель діагностики діяльності підприємств у конкурентному середовищі, що базується на методології комплексного економічного аналізу та внутрішнього контролю з використанням фінансових і нефінансових показників. Для оцінювання конкурентних переваг компанії пропонуємо алгоритм розрахунку інтегрального показника рівня його конкурентоспроможності з використанням збалансованої системи показників.

Наукова новизна. У процесі дослідження розроблено науково-методологічний підхід до комплексної оцінки впливу дослідницької складової на розвиток конкурентної стратегії підприємства. На відміну від існуючих, цей підхід передбачає:

- розроблення інтегрованої системи комплексного економічного аналізу та внутрішнього контролю за бізнес-процесами підприємств із використанням сучасних інформаційних технологій, що дає змогу оцінювати їх конкурентоспроможність, формувати стратегію розвитку;

- методичні процедури внутрішнього контролю діяльності підприємства з використанням фінансових та операційних бюджетів і управлінських звітів на основі збалансованої системи показників, із використанням CVP-аналізу, що дає змогу формувати гнучкі бюджети.

Практична значимість. Результати дослідження можуть бути використані практиками, науковцями, державними службовцями для моніторингу розвитку корпоративної архітектури, дослідження процесів розвитку підприємства.

Ключові слова: конкурентне середовище, комплексний економічний аналіз, внутрішній контроль, збалансована система показників

Recommended for publication by K. Shaposhnykov, Doctor of Economic Sciences. The manuscript was submitted 14.02.21. 